\title{
Production of the Novel C-C Chemokine MCP-4 by Airway Cells and Comparison of Its Biological Activity to Other C-C Chemokines
}

\author{
Cristiana Stellato, Paul Collins, ${ }^{*}$ Paul D. Ponath, " Dulce Soler, ${ }^{\|}$Walter Newman, ${ }^{\|}$Greg La Rosa, ${ }^{\|}$Haodong Li, ${ }^{\ddagger}$ John White, ${ }^{\S}$ \\ Lisa M. Schwiebert, Carol Bickel, Mark Liu, Bruce S. Bochner, Timothy Williams, ${ }^{*}$ and Robert P. Schleimer \\ Johns Hopkins Asthma and Allergy Center, Division of Clinical Immunology, Baltimore, Maryland 21224; *National Heart and Lung \\ Institute, Department of Applied Pharmacology, London SW3-6LY, United Kingdom; ${ }^{\ddagger}$ Human Genome Sciences, Rockville, Maryland

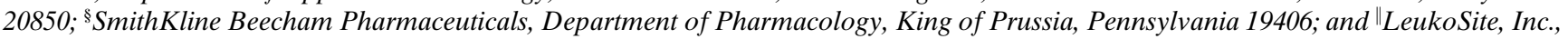 \\ Cambridge, Massachusetts 02142
}

\begin{abstract}
Monocyte chemotactic protein-4 (MCP-4) is a newly identified $\mathrm{C}-\mathrm{C}$ chemokine with potent eosinophil chemoattractant properties. We describe studies of its biological activity in vitro to induce chemotaxis of peripheral blood eosinophils and to induce histamine release from IL-3-primed peripheral blood basophils. MCP-4 and eotaxin caused a similar rise in eosinophil intracytoplasmic $\mathrm{Ca}^{2+}$ and complete cross-desensitization. MCP-4 also abolished the eosinophil $\mathrm{Ca}^{2+}$ response to MCP-3 and partially desensitized the response to macrophage inflammatory protein- $1 \alpha$. MCP-4 activated cell migration via either CCR2b or CCR3 in mouse lymphoma cells transfected with these chemokine receptors. MCP-4 inhibited binding of ${ }^{125}$ I-eotaxin to eosinophils and CCR3-transfected cells and inhibited ${ }^{125}$ I-MCP-1 binding to CCR2b-transfectants. MCP-4 mRNA was found in cells collected in bronchoalveolar lavage of asthmatic and nonasthmatic subjects and was prominently expressed in human lung and heart. MCP-4 mRNA was expressed in several human bronchial epithelial cell lines after cytokine stimulation. Pretreatment of BEAS-2B epithelial cells with the glucocorticoid budesonide inhibited MCP-4 mRNA expression. These features make MCP- 4 a candidate for playing a role in eosinophil recruitment during allergic respiratory diseases. (J. Clin. Invest. 1997. 99:926-936.) Key words: allergy • chemokines $\bullet$ eosinophils $\cdot$ glucocorticoids $\bullet$ inflammation
\end{abstract}

\section{Introduction}

Eosinophils are now known to be central effector cells in the pathogenesis of allergic airways disease including asthma and rhinitis $(1,2)$. In many allergic conditions, selective recruitment of eosinophils is observed (i.e., in the relative absence of neutrophils) (3). While considerable progress has been made

\footnotetext{
Address correspondence to Robert P. Schleimer, Ph.D., Professor of Medicine, Johns Hopkins Asthma and Allergy Center, Room 3A.62, 5501 Hopkins Bayview Circle, Baltimore, MD 21224-6801. Phone: 410-550-2135; FAX: 410-550-2130; E-mail: rschleim@welchlink.welch. jhu.edu

Received for publication 9 May 1996 and accepted in revised form 12 December 1996.
}

J. Clin. Invest.

(C) The American Society for Clinical Investigation, Inc. 0021-9738/97/03/0926/11 \$2.00

Volume 99, Number 5, March 1997, 926-936 in understanding the pathways by which eosinophils may be selectively recruited to a site of allergic disease, numerous uncertainties about these pathways still remain. Endothelial activation and expression of VCAM-1 are key events in the initial phases of eosinophil recruitment (3-7). Activation of circulating eosinophils by IL-5 selectively promotes their longevity and increases their migratory and adhesive properties (8-11). Recently, it has been appreciated that chemokines are key cytokines in the regulation of the migration of numerous cell types (12-15). Numerous chemokines have been identified which have the ability to cause eosinophil migration, including RANTES (Regulated upon Activation, Normal T cell Expressed and presumably Secreted), ${ }^{1}$ monocyte chemotactic protein-3 (MCP-3), macrophage inflammatory protein-1 $\alpha$ (MIP-1 $\alpha$ ), and eotaxin (16-22). RANTES is considerably more potent than MCP-3 and MIP-1 $\alpha$ (21). Recent comparative data using human cells indicate that eotaxin has a potency comparable with MCP-3 and RANTES in causing eosinophil migration (16). Allergen challenge studies in humans and animals now indicate that MCP-3, RANTES, and eotaxin are all present at significantly increased levels in either airways or skin (23-26). The importance of the above mentioned chemokines in allergic inflammation is supported by their eosinophil-selective chemoattractant properties, the finding that antigen challenge increases their quantity at a local tissue site, and recent findings that a profound eosinophil-rich infiltrate is elicited by experimental challenge of dogs or humans with RANTES (27, 28 ) or by challenge of guinea pigs with eotaxin $(20,29)$. Further, the local accumulation of eosinophils induced by eotaxin in guinea pig skin has been shown to be considerably enhanced by a novel action of IL- 5 to release a rapidly mobilizable pool of eosinophils from the bone marrow into the circulation (30). Identification of chemokine receptors, which are all members of the seven transmembrane spanning receptor family, has been progressing at a rapid rate. There are known to be four receptors for $\mathrm{CXC}$ chemokines and at least five $\mathrm{C}-\mathrm{C}$ chemokine receptors (CCR), which are all members of the serpentine seven transmembrane receptor family (31-38). The Duffy blood group antigen, which is now known to be a receptor for the intracellular malarial parasite plasmodium vivax, has been shown to be a promiscuous receptor for C-C and C-X-C chemokines (36, 39-41).

In this study, we have identified a novel chemokine termed

1. Abbreviations used in this paper: $\mathrm{BAL}$, bronchoalveolar lavage; $\left[\mathrm{Ca}^{2+}\right]_{i}$, intracellular cytosolic free calcium; CCR, C-C chemokine receptors; MCP, monocyte chemotactic protein; MIP, macrophage inflammatory protein; RANTES, Regulated upon Activation, Normal $T$ cell Expressed and presumably Secreted. 
MCP-4 (previously referred to as CK $\beta 10$ ) which was discovered via large-scale cDNA sequencing by Human Genome Sciences. Preliminary screens among 10 novel chemokines identified by this method indicated that MCP-4 is a potent eosinophil chemoattractant (42). This was confirmed by Uguccioni et al. (43) who further characterized MCP-4 as a chemoattractant for monocytes and $\mathrm{T}$ lymphocytes. We report here that MCP-4 induces eosinophil migration and calcium mobilization and potentiates basophil histamine release. Analysis of receptor binding competition and functional assays indicates that MCP-4 can functionally activate more than one chemokine receptor. MCP-4 mRNA was detected by RT-PCR in RNA samples from bronchoalveolar lavage (BAL) and by Northern blot in human lung tissue. MCP-4 mRNA was found to be induced in cultured airway epithelial cell lines by exposure to cytokines and to be suppressed by the potent glucocorticoid budesonide.

\section{Methods}

Reagents. The following reagents were purchased from the indicated sources: Hanks' F12, Hanks' F12-K (BioWhittaker, Inc., Walkersville, MD), LHC-8 (Biofluids, Inc., Rockville, MD), DMEM, $\mathrm{Ca}^{2+}$ - and $\mathrm{Mg}^{2+}$-free HBSS, FCS, L-glutamine, penicillin/streptomycin solution, agarose, formamide, reverse transcription reagents kit (MMLV reverse transcriptase, $5 \times$ buffer, DTT), RNAse inhibitor, PCR reagents kit (10× buffer, Taq polymerase, $\mathrm{MgCl}$ ) (GIBCO-BRL, Gaithersburg, MD), MicrofastTrack poly(A) ${ }^{+}$RNA isolation kit (Invitrogen Corp., San Diego, CA), RNAzol B (Tel-Test Inc., Friendswood, TX), oligoDT (Boehringer-Mannheim, Indianapolis, IN), Percoll, deoxynucleotides (Pharmacia, Piscataway, NJ), chloroform, isopropanol, formaldehyde (Fisher Scientific, Fernwood, NJ), Pipes, salmon sperm DNA, DMSO, erythrosin B (Sigma Chemical Co., St. Louis, MO), Genescreen membranes, and $\left[\alpha^{-32} \mathrm{P}\right] \mathrm{dATP}$ (DuPontNEN, Boston, MA). Dynabeads were purchased from Dynal, Inc. (Great Neck, NY), CD16 monoclonal antibody from Immunotech, Inc. (Westbrook, ME), and goat anti-human IgE from Kirkegaard \& Perry Laboratories, Inc. (Gaithersburg, MD). The multiple tissue Northern blot and ExpressHyb ${ }^{\mathrm{TM}}$ solution were purchased from Clontech (Palo Alto, CA). Primers for MCP-4 and $\beta$-actin were generated by Bioserva Biotechnologies, Inc. (Laurel, MD). Human recombinant MCP-3 and MIP- $1 \alpha$ were purchased from Peprotech, Inc. (Rocky Hill, NJ). Human recombinant MCP-1, RANTES, IL-3, $\mathrm{TNF} \alpha$, and IFN $\gamma$ were purchased from R\&D Systems (Minneapolis, $\mathrm{MN})$. For the expression of human recombinant MCP-4, the MCP-4 coding region was cloned into a baculovirus expression vector. The vector was cotransfected together with linearized baculovirus DNA (BaculoGold ${ }^{\mathrm{TM}}$; Pharmingen, San Diego, CA) into Sf9 cells (No. CRL 1711; American Type Culture Collection, Rockville, MD). Recombinant MCP-4 was purified from the transfected Sf9 cell culture supernatant by the following chromatography procedures: cation ex-

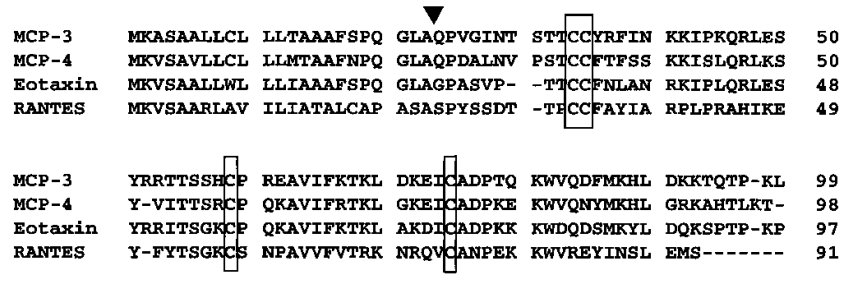

Figure 1. Amino acid sequence alignment of human MCP-3, MCP-4, eotaxin, and RANTES. Conserved cysteine residues are indicated by boxes; the arrowhead indicates the predicted $\mathrm{NH}_{2}$ terminus of the mature proteins after cleavage of the signal peptide. change, heparin affinity, and size exclusion (poros $50 \mathrm{HS}$, poros 20 HE1, Perseptive Biosystem and Sephacryl S200 HR; Pharmacia). Human recombinant eotaxin was chemically synthesized as described $(16,44)$. The amino acid sequences of MCP-4, eotaxin, RANTES, and MCP-3 are shown in Fig. 1. Budesonide was a generous gift of Drs. Per Andersson and Ralph Brattsand (Astra Draco, Lund, Sweden) and was stored as a $0.1 \mathrm{M}$ stock in DMSO at $-20^{\circ} \mathrm{C}$.

Culture of epithelial cell lines and collection of BAL cells. Three cell lines derived from human bronchial epithelium, and transformed by an adenovirus 12-SV40 hybrid virus, have been used. The BEAS-2B cell line (45) has been generously supplied by Dr. Curtis Harris (National Institutes of Health). The IB3 cell line (46) was kindly provided by Dr. Pamela Zeitlin (Johns Hopkins University). The A549 cell line was purchased from American Type Culture Collection. Cells were cultured in $25-\mathrm{cm}^{2}$ tissue culture flasks and maintained in F12/DME medium (BEAS-2B), F12-K medium (A549 cells), or LHC-8 (IB3-1 cells), each with $5 \%$ heat-inactivated FCS, penicillin $(100 \mathrm{U} / \mathrm{ml})$, and streptomycin $(100 \mathrm{mg} / \mathrm{ml})$. Cells were detached from the flasks with $0.02 \%$ trypsin in HBSS for passage and cultures were maintained until passage 45 . Cells were cultured at $37^{\circ} \mathrm{C}$ with $5 \% \mathrm{CO}_{2}$ in humidified air. All experiments were performed after the cells reached $80-90 \%$ confluence, at which time 5-8 $810^{6}$ cells/flask were recovered. Viability of cells, assessed by staining with erythrosin B, was always $>95 \%$ of cells harvested. BAL cells from normal subjects and asthmatic patients were harvested as described previously (47). BAL donors were divided into groups of normal subjects or asthmatic donors on the basis of detailed clinical history, with particular focus on respiratory symptoms. Asthmatic subjects were characterized as mild atopic asthmatics requiring no regular medication for control of asthma. Atopic status and airway reactivity of asthmatic subjects were determined according to previously described protocols (47).

Basophil purification. Basophil-enriched suspensions were prepared by density centrifugation on Percoll gradients as described (48). Briefly, whole blood was anticoagulated with 0.1 M EDTA, diluted with an equal volume of Pipes buffer, and the density adjusted to $1.065 \mathrm{~g} / \mathrm{ml}$ with $100 \%$ isotonic Percoll. The blood-Percoll mixture was layered over a cushion of Percoll of density $1.079 \mathrm{~g} / \mathrm{cm}^{3}$ and then centrifuged at $400 \mathrm{~g}$ for $15 \mathrm{~min}$ at $22^{\circ} \mathrm{C}$. After centrifugation, all procedures were carried out at $4^{\circ} \mathrm{C}$ to minimize cell activation. The cells were collected from the supernatant and from the plasma-Percoll interface, washed once in EDTA-saline to remove the Percoll, twice in PAG-EDTA, and the number and percentage of basophils in each fraction determined. The mean percentage of basophils found in these fractions ranged from 5 to $12 \%$, as determined by cell counts in Spiers-Levy chambers using Alcian blue (49).

Eosinophil purification. Human granulocytes were isolated from EDTA-anticoagulated venous blood of normal donors or patients with asymptomatic allergic rhinitis or asthma by Percoll $(1.090 \mathrm{~g} / \mathrm{ml})$ gradient centrifugation at room temperature. After centrifugation, all procedures were carried out at $4^{\circ} \mathrm{C}$ to minimize cell activation. Red blood cells were removed by hypotonic lysis followed by removal of CD16-positive cells (neutrophils) using an immunomagnetic bead technique (50). Eosinophil purity (based on examination of DiffQuik-stained cytocentrifugation preparations) was $99 \pm 1 \%$ and viability (based on erythrosin B dye exclusion) was $99 \pm 1 \%(n=7)$. For neutrophil purification, EDTA-anticoagulated venous blood of normal donors was layered over Percoll $(1.080 \mathrm{~g} / \mathrm{ml})$, and centrifuged for $20 \mathrm{~min}$ at room temperature. After centrifugation, red blood cells were removed by hypotonic lysis. Neutrophil purity was $98 \pm 1 \%$ and viability was $98 \pm 1 \%(n=5)$. Eosinophils were labeled with ${ }^{51} \mathrm{Cr}$ as described $(51,52)$, washed extensively, and resuspended in PAGCM buffer (Pipes buffer with $0.003 \%$ BSA, $0.1 \%$ D-glucose, $1 \mathrm{mM} \mathrm{CaCl}_{2}$, $1 \mathrm{mM} \mathrm{MgCl} 2$ ) for chemotaxis studies as described below.

Chemotaxis experiments. Chemotaxis experiments were performed using a modified Boyden chamber technique as described previously (53). Briefly, $25 \mu \mathrm{l}$ of PAGCM buffer or various concentrations of the stimuli in the same buffer were placed in triplicate in the lower chamber. A $5-\mu \mathrm{m}$ pore-size polycarbonate membrane (Nucleopore Corp., 
Pleasanton, CA) separated the upper and lower chamber. Eosinophils $\left(10^{5}\right)$ or neutrophils $\left(1.5 \times 10^{6}\right)$ resuspended in PAGCM were placed in each well of the upper chamber, on top of the membrane. The chamber was then incubated for $30 \mathrm{~min}$ at $37^{\circ} \mathrm{C}$ in $5 \% \mathrm{CO}_{2} /$ air, after which the chamber was disassembled. The membrane was removed and washed in PAG to remove the nonmigrating eosinophils from the upper surface, scraped, and then stained with Wright's stain. Eosinophils from 10 high-power fields of triplicate wells were identified and counted. To assess whether MCP-4 induced a chemokinetic rather than a chemotactic effect on eosinophil migration, some experiments were conducted in the absence or presence of MCP-4 (1 or 100 $\mathrm{nM})$ in the upper chamber of the apparatus.

Chemotaxis experiments with the mouse pre-B lymphoma cell line 300.19 transfected with CCR2b and with the mouse pre-B lymphoma cell line L1.2 transfected with CCR3 were performed as described (37). Briefly, chemokines in a $600-\mu l$ volume of assay media, consisting of equal parts of M199 medium and RPMI 1640 medium plus $0.5 \%$ BSA, were added to the bottom chamber of 24-well Biocoat $^{\circledR}$ transwell tissue culture plates (Costar Corp., Cambridge, MA) and $10^{6}$ cells were added to the top chamber in a $100-\mu l$ volume. The plates were incubated at $37^{\circ} \mathrm{C}$, in $5 \% \mathrm{CO}_{2} / 95 \%$ air for $4 \mathrm{~h}$. Cells that had migrated to the bottom chamber were counted using a FACScan ${ }^{\circledR}$. Chemotaxis of the wild-type cell lines was not observed in response to any of the chemokines used in this study at the concentration range tested (data not shown).

Basophil histamine release. Basophils were partially purified as described above, resuspended in PAGCM buffer, and exposed to chemokines either with or without a prior 10-min exposure to IL-3 $(10 \mathrm{ng} / \mathrm{ml})$ as indicated in the results section. Basophils were pelleted by centrifugation, and supernatants were assayed using a spectrofluorometric assay for histamine as described previously $(54,55)$. A separate aliquot of cells was lysed with perchlorate to determine total histamine content, and histamine release was expressed as a percentage of the total after subtracting the spontaneous release (always $<10 \%$ ).

Analysis of intracytoplasmic calcium in eosinophils. Eosinophils $\left(10^{7}\right.$ cells $\left./ \mathrm{ml}\right)$ were incubated with $1 \mu \mathrm{M}$ Fura-2 acetoxymethyl ester at $37^{\circ} \mathrm{C}$ for $30 \mathrm{~min}$. After two washes, cells were resuspended at $1 \times$ $10^{6}$ cells $/ \mathrm{ml}$ in $10 \mathrm{mM} \mathrm{Ca}{ }^{2+} / \mathrm{Mg}^{2+}$-free PBS (pH 7.4) containing 10 $\mathrm{mM}$ Hepes, $10 \mathrm{mM}$ D-glucose, and $0.25 \%$ low endotoxin BSA. Cells $(1.2 \mathrm{ml})$ were dispensed into quartz cuvettes with constant stirring and the external calcium concentration was adjusted to $1 \mathrm{mM}$ with $\mathrm{CaCl}_{2}$. Changes in fluorescence were monitored at $37^{\circ} \mathrm{C}$ using a spectrophotometer (LS50; Perkin Elmer Corp., Beaconsfield, Bucks, United Kingdom) at excitation wavelengths $340 \mathrm{~nm}$ and $380 \mathrm{~nm}$ and emission wavelength $510 \mathrm{~nm}$. Calculation of calcium concentration was performed using a $K_{\mathrm{d}}$ for $\mathrm{Ca}^{2+}$-binding of $224 \mathrm{nM}$. In all experiments, agonists were added in a volume of $24 \mu \mathrm{l}$, the first addition being $50 \mathrm{~s}$ after commencing recording and the second addition, for desensitization studies, being $140 \mathrm{~s}$ later.

${ }^{125}$ I-Chemokine binding assay. Radiolabeled chemokines were obtained from Amersham Life Science, Inc. (Arlington Heights, IL). The binding reaction $(200 \mu \mathrm{l})$ was performed with $0.1 \times 10^{6}$ eosinophils or $0.5 \times 10^{6}$ receptor transfectants with $0.1 \mathrm{nM}^{125}$ I-eotaxin or $0.2 \mathrm{nM}^{125} \mathrm{I}-\mathrm{MCP}-1$, for $1 \mathrm{~h}$ at $37^{\circ} \mathrm{C}$ in binding buffer $(50 \mathrm{mM}$ Hepes, pH 7.5, $1 \mathrm{mM} \mathrm{CaCl}_{2}, 5 \mathrm{mM} \mathrm{MgCl} 2,0.5 \%$ BSA, $0.02 \% \mathrm{NaAzide}$. For competition of binding with unlabeled chemokines, the indicated concentration of chemokine was included in the binding reaction. Briefly, cells were resuspended in binding buffer at $1 \times 10^{6} / \mathrm{ml}$ (or $5 \times$ $10^{6} / \mathrm{ml}$ for transfectants) and $100-\mu l$ aliquots were added to microcentrifuge tubes containing cold chemokine in binding buffer, followed by the addition of radiolabeled chemokine resuspended in the same buffer. Nonspecific binding was determined by performing the binding reactions in the presence of a 1,000-fold excess of cold chemokine. After incubation, the reaction tubes were centrifuged at $8,000 \mathrm{~g}$ for 3 min and pellets washed with $150 \mu \mathrm{l}$ of wash buffer (binding buffer plus $0.5 \mathrm{M} \mathrm{NaCl}$ ). Cells were briefly vortexed at low speed and then centrifuged at $16,000 \mathrm{~g}$ for $3 \mathrm{~min}$. The resulting pellet was transferred in $150 \mu$ l of the same buffer to polystyrene tubes for gamma counting.
Experimental design for MCP-4 mRNA detection in epithelial cell lines. In experiments assessing the effect of cytokines on MCP-4 gene expression, BEAS-2B, A549, and IB3-1 monolayers at $80-90 \%$ confluence were treated with either control medium, TNF $\alpha(1-100 \mathrm{ng} /$ $\mathrm{ml})$, IFN $\gamma(1-100 \mathrm{ng} / \mathrm{ml})$, or combinations of these two cytokines for $24 \mathrm{~h}$. Cells were harvested and poly $(\mathrm{A})^{+}$RNA extracted for Northern blot analysis according to the manufacturer's protocol (Invitrogen). For time course experiments, BEAS-2B cultures were harvested after stimulation with TNF $\alpha(100 \mathrm{ng} / \mathrm{ml})$ for $0.25,0.5,1,3,6$, or $24 \mathrm{~h}$. For inhibition studies with the glucocorticoid budesonide, BEAS-2B cultures were preexposed for $24 \mathrm{~h}$ to budesonide $\left(10^{-7} \mathrm{M}\right)$ or an equivalent amount of DMSO diluent and then treated with TNF $\alpha$ (1-100 $\mathrm{ng} / \mathrm{ml})$ or the combination of TNF $\alpha$ and IFN $\gamma(100 \mathrm{ng} / \mathrm{ml}$ each $)$ for an additional $24 \mathrm{~h}$ in the continued presence of steroid or diluent.

Northern blot analysis of MCP-4. $2 \mu \mathrm{g}$ of $\operatorname{poly}(\mathrm{A})^{+} \mathrm{RNA}$ was diluted in $50 \%$ formamide, $6 \%$ formaldehyde, $1 \mathrm{mM}$ EDTA, and $10 \%$ glycerol in $8 \mathrm{mM}$ sodium acetate buffer and heated at $55^{\circ} \mathrm{C}$ for 10 min. Samples were loaded and electrophoresed on $1 \%$ agarose gels containing $6 \%$ formaldehyde, $1 \mathrm{mM}$ EDTA, in $8 \mathrm{mM}$ sodium acetate buffer ( $\mathrm{pH} 8.3$ ). Gels were run for $2 \mathrm{~h}$ at $60 \mathrm{~V}$ and blotted onto a Genescreen nylon membrane using a PosiBlot ${ }^{\mathrm{TM}}$ pressure blotter (Stratagene, La Jolla, CA). RNA was fixed to the nylon membrane by ultraviolet cross-linking using an FB-UVXL-100 UV cross-linker (Fisher-Biotech, Pittsburgh, PA), followed by overnight incubation in prehybridization buffer at $37^{\circ} \mathrm{C}$ and then by overnight hybridization at the same temperature with $1 \times 10^{6} \mathrm{cpm} / \mathrm{ml}$ of ${ }^{32} \mathrm{P}$-labeled probe. The random hexamer priming method was used to label the cDNA probe, which is an EcoRI-XhoI fragment of $1 \mathrm{~kb}$ containing the coding region of MCP-4. Hybridization and prehybridization buffer was $2 \times$ Pipes, $50 \%$ deionized formamide, $0.5 \%$ SDS, $100 \mu \mathrm{g} / \mathrm{ml}$ salmon sperm DNA. Membranes were washed twice in $2 \times$ SSC, $0.1 \%$ SDS for $10 \mathrm{~min}$ at room temperature, then four times in the same buffer for $15 \mathrm{~min}$ at $60^{\circ} \mathrm{C}$ and twice in $0.2 \times \mathrm{SSC}, 0.1 \%$ SDS for $15 \mathrm{~min}$ at $60^{\circ} \mathrm{C}$. Autoradiographs were quantified by video densitometry using a gel documentation system configured by UVP (San Gabriel, CA) interfaced with a Macintosh Centris 610 containing Image 1.53 software (NIH Public Software, Bethesda, MD). Equal loading of lanes and integrity of mRNA were assessed by blotting of the membranes with a probe specific for G3PDH (Clontech, Palo Alto, CA). A multiple tissue Northern blot (Clontech) was prehybridized for 30 min with ExpressHyb ${ }^{\mathrm{TM}}$ solution (Clontech) at $68^{\circ} \mathrm{C}$ and then hybridized for $1 \mathrm{~h}$ with $1 \times 10^{6}$ $\mathrm{cpm} / \mathrm{ml}$ of the ${ }^{32} \mathrm{P}$-labeled probe described above at $68^{\circ} \mathrm{C}$. The membrane was then washed twice at room temperature for 20 min with $2 \times$ SSC, $0.05 \%$ SDS, twice with the same buffer at $50^{\circ} \mathrm{C}$ and then twice for $20 \mathrm{~min}$ with $0.2 \times \mathrm{SSC}, 0.1 \% \mathrm{SDS}$ at $50^{\circ} \mathrm{C}$. Equal loading of lanes and integrity of mRNA were assessed by blotting of the membranes with a probe specific for $\beta$-actin (Clontech).

$R T-P C R$ analysis of MCP-4. Total RNA was extracted using the RNAzol B technique (56) from cells recovered from BAL of asthmatic subjects as described (47). For the generation of the MCP-4 first-strand cDNA, reverse transcription was performed as follows: aliquots of $1 \mu \mathrm{g}$ of total RNA in $13 \mu \mathrm{l}$ diethylpyrocarbonate-treated water were mixed with $50 \mathrm{pmol}$ of oligo(dT) and heated at $70^{\circ} \mathrm{C}$ for $10 \mathrm{~min}$, then chilled on ice. Subsequently, the following reagents were added to the tube: $4 \mu \mathrm{l}$ of $5 \times$ synthesis buffer $(250 \mathrm{mM}$ Tris, $375 \mathrm{mM}$ $\mathrm{KCl}, 15 \mathrm{mM} \mathrm{MgCl}_{2}$ ), $2 \mathrm{mM}$ dNTP mix, $10 \mathrm{mM}$ DTT, and $100 \mathrm{U}$ of reverse transcriptase in a total volume of $20 \mu \mathrm{l}$. The reaction was conducted in a Hybaid omnigene thermocycler for $30 \mathrm{~min}$ at $37^{\circ} \mathrm{C}$ and then for $5 \mathrm{~min}$ at $99^{\circ} \mathrm{C}$. PCR was conducted in the same thermocycler according to the method previously described (57). For the PCR reaction, $2 \mu \mathrm{l}$ of the first-strand DNA was mixed with $3^{\prime}$ and $5^{\prime}$ primers (20 pmol each), $1 \mathrm{U}$ of Taq DNA polymerase, $5 \mu \mathrm{l} 10 \times$ PCR buffer (200 mM Tris, 500 mM KCl, 2 mM MgCl, pH 8.4), $200 \mu$ M dNTP mix, and water to bring final reaction volume to $50 \mu \mathrm{l}$. The samples were sealed with mineral oil and the PCR reaction was performed as follows: first, a 5-min cycle with a denaturing temperature of $95^{\circ} \mathrm{C}$, followed by 30 cycles of $95^{\circ} \mathrm{C}$ for $1 \mathrm{~min}, 55^{\circ} \mathrm{C}$ for $1 \mathrm{~min}$, and $70^{\circ} \mathrm{C}$ for 2 min. A final elongation step at $72^{\circ} \mathrm{C}$ for $10 \mathrm{~min}$ was included. The 
cDNA for MCP-4 and water were used as positive and negative controls, respectively. The nucleotide sequences of MCP-4 and $\beta$-actin primers were: CCC GCA TGC AGC CAG ATG CAC TCA ACG (5' primer) and AAA GGA TCC AGT CTT CAG GGT GTG AGC T ( $3^{\prime}$ primer), and TGA CGG GGT CAC CCA CAC TGT GCC CAT CTA (5' primer) and CTA GAA GCA TTG CGG TGG ACG ATG GAG GG ( $3^{\prime}$ primer), respectively. At the end of the reaction, PCR products were separated via electrophoresis on a $2 \%$ agarose gel. The amplified MCP-4 mRNA was identified based upon the anticipated molecular size by comparison with positive control and a DNA ladder of known molecular sizes.

Statistical analysis. Analysis of data was performed using Statview software (Abacus Concept, Inc., Berkeley, CA) on a Macintosh IIsi computer. Data are expressed as mean \pm SEM. For the eosinophil and neutrophil chemotaxis data and for basophil histamine release, statistical differences between groups were tested using ANOVA with a post-hoc analysis (Fisher PLSD test). $P<0.01$ was considered significant for chemotaxis experiments, and $P<0.05$ was considered significant for basophil histamine release experiments. Statistical analysis of the data from the calcium mobilization experiments was performed using a two-tailed, paired Student's $t$ test. $P<0.05$ was considered significant.

\section{Results}

Mass sequencing of cDNA derived from various cell types has proven to be an effective way to identify previously undiscovered human genes $(58,59)$. We initially set out to determine whether there were eosinophil-active chemokines among 10 molecules discovered by mass cDNA sequencing which had been predicted to be members of the $\mathrm{C}-\mathrm{C}$ branch of the chemokine family based on primary amino acid sequence. Among these chemokines, one in particular, MCP-4, which has $60 \%$ homology at the amino acid level with MCP-3 (Fig. 1), was found to be a potent and effective eosinophil chemoattractant in the microchemotaxis assay. In comparison with a panel of eosinophil-targeting C-C chemokines, MCP-4 induced mi- gration of eosinophils purified from peripheral blood at concentrations between 1 and $100 \mathrm{nM}$, a concentration range that also elicited significant eosinophil migration in response to RANTES and eotaxin (Fig. 2, A). The addition of 1 or $100 \mathrm{nM}$ MCP-4 to the upper chamber in the chemotaxis assay prevented cell migration in response to MCP-4 (1-100 nM), indicating that this response is chemotactic as opposed to chemokinetic (data not shown). Overnight incubation with IL-5 (5 $\mathrm{ng} / \mathrm{ml}, n=4)$ increased eosinophil migration both in the presence of buffer alone $(373 \pm 132 \%$ of control migration in the absence of IL-5) and of $10 \mathrm{nM} \mathrm{MCP}-4$ (252 $\pm 73 \%$ of $10 \mathrm{nM}$ MCP-4-induced migration in the absence of IL-5). When neutrophils were used in the chemotaxis assay (Fig. 2 B), IL-8 was found to induce a marked, concentration-dependent neutrophil migration, while neither RANTES nor MCP-4 caused concentration-dependent migration of neutrophils.

Studies to date indicate that basophils and eosinophils have similar response patterns to chemokines (19). Previously, MCP-1 and MCP-3 have been shown to be the most effective basophil activators among the chemokines (19). To extend the analysis of the actions of MCP-4, histamine release experiments were performed to determine whether MCP-4 activates basophils. Results in Table I indicate that MCP-4 (100 nM) induced little histamine release in basophils not primed by exposure to IL-3. MCP-4 induced significant histamine release from basophils preincubated with IL-3 $(10 \mathrm{ng} / \mathrm{ml})$, with a magnitude similar to that obtained with MCP-3. Histamine release induced by MCP-4 in IL-3-primed basophils was found to be concentration dependent in a concentration range from $3 \times$ $10^{-8} \mathrm{M}$ to $10^{-6} \mathrm{M}(n=3$, data not shown $)$.

To study further the activation of human eosinophils by MCP-4, we determined its effects on changes in free cytosolic $\mathrm{Ca}^{2+}$ levels $\left(\left[\mathrm{Ca}^{2+}\right]_{\mathrm{i}}\right)$ in purified eosinophils in comparison with other eosinophil-activating $\mathrm{C}-\mathrm{C}$ chemokines. Data shown in Fig. $3 A$ show that MCP-4 and eotaxin caused a concentration-

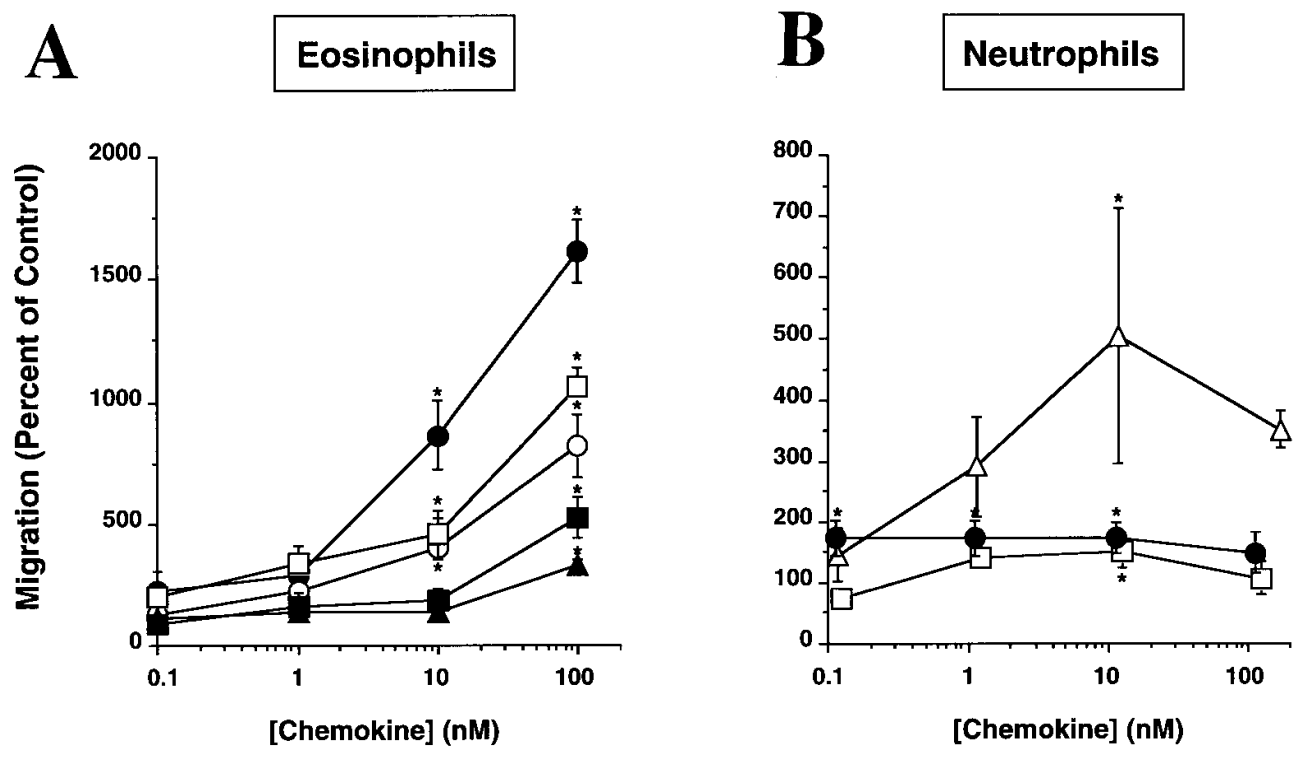

Figure 2. (A) Chemotaxis of purified peripheral blood eosinophils induced by $\mathrm{C}-\mathrm{C}$ chemokines $(n=5-7)$. Chemotaxis was assessed using Boyden microchambers as described in Methods. The number of eosinophils migrating in the control condition was $38 \pm 6$. The percentage of control eosinophils migrating in response to PAF $\left(10^{-7} \mathrm{M}\right)$ was $1,001 \pm 144$. $* P<0.01 \mathrm{com}-$ pared with control migration. Filled circles, MCP-4; open circles, eotaxin; open squares, RANTES; filled squares, MCP-3; filled triangles, MCP-1; open triangles, MIP-1 $1 \alpha .(B)$ Chemotaxis of purified neutrophils induced by RANTES, MCP-4, and IL-8 $(n=3-5)$. The number of neutrophils migrating in the control condition was $96 \pm 15$. $* P<0.05$ compared with control migration. Filled circles, MCP-4; open squares, RANTES; open triangles, IL-8. 
Table I. Comparison of the Effect of Chemokines on Basophil Histamine Release in the Absence or Presence of IL-3

\begin{tabular}{lccc}
\hline & \multicolumn{3}{c}{ Percent histamine release } \\
\cline { 2 - 4 } \multicolumn{1}{c}{ Stimulus } & Control & IL-3 & $n$ \\
\hline MCP-1 $(100 \mathrm{nM})$ & $19 \pm 6^{*}$ & $44 \pm 10^{\ddagger}$ & 4 \\
MCP-3 $(100 \mathrm{nM})$ & $3 \pm 1$ & $17 \pm 5$ & 7 \\
MCP-4 $(100 \mathrm{nM})$ & $3 \pm 1$ & $20 \pm 6^{\ddagger}$ & 7 \\
RANTES $(100 \mathrm{nM})$ & $1 \pm 0.6$ & $8 \pm 4$ & 4 \\
Eotaxin $(100 \mathrm{nM})$ & $3 \pm 1$ & $13 \pm 6$ & 4 \\
MIP-1 $\alpha(100 \mathrm{nM})$ & $1 \pm 0.6$ & $9 \pm 3$ & 6 \\
Anti-IgE $(0.1 \mu \mathrm{g} / \mathrm{ml})$ & $41 \pm 10$ & $52 \pm 9^{\ddagger}$ & 6 \\
rHuIL-3 $(10 \mathrm{ng} / \mathrm{ml})$ & & $7 \pm 2$ & 6 \\
& & & \\
\hline
\end{tabular}

${ }^{\ddagger} P<0.05$ when compared with histamine release caused by the same stimulus in non-IL-3-treated basophils. *Values shown are mean \pm SEM of percent histamine release.

dependent $\left[\mathrm{Ca}^{2+}\right]_{\mathrm{i}}$ elevation with a similar potency, at concentrations ranging from 0.3 to $3 \mathrm{nM}$. In another series of four experiments, the $\left[\mathrm{Ca}^{2+}\right]_{\mathrm{i}}$ induced by $1 \mathrm{nM} \mathrm{MCP}-4(205 \pm 30 \mathrm{nM})$ was equal to or greater than that induced by $10 \mathrm{nM}$ RANTES $(213 \pm 40 \mathrm{nM})$, MIP- $1 \alpha(163 \pm 21 \mathrm{nM})$, or MCP-3 $(173 \pm 7 \mathrm{nM})$. $\mathrm{MCP}-4$, at concentrations up to $100 \mathrm{nM}$, did not elicit any significant $\left[\mathrm{Ca}^{2+}\right]_{\mathrm{i}}$ elevation in purified neutrophils (data not shown).

Thus far, there are at least five known CCRs (31). At least two CCRs which could potentially mediate the effects of MCP-4, CCR1 and 3, have been identified on eosinophils (31, 37). Therefore, we initiated experiments of desensitization of $\mathrm{Ca}^{2+}$ influx to shed some light on the receptor(s) mediating MCP-4 activity in eosinophils. A dose-dependent cross-desensitization was observed between MCP-4 and eotaxin (Fig. $3 B$ ). Fig. 4 shows that the response to MCP-4 $(1 \mathrm{nM})$ was desensitized by preincubation with either MCP-3 or MIP-1 $\alpha(10 \mathrm{nM})$ although the response to $10 \mathrm{nM}$ MCP-4 was less susceptible to desensitization. MCP-4 (3 nM) completely abolished the response to MCP-3 $(10 \mathrm{nM})$ and partially blocked the response to MIP-1 $\alpha(10 \mathrm{nM})$ (complete desensitization of the response to $10 \mathrm{nM}$ MIP- $1 \alpha$ was achieved when $10 \mathrm{nM}$ MCP-4 was administered; data not shown). The cross-desensitization between the C-C chemokines was specific because the calcium mobilization induced by subsequent addition of either C5a or leukotriene $\mathrm{B}_{4}$ was unaffected (data not shown). Although these experiments indicate that MCP-4 shares at least one receptor subtype in common, respectively, with eotaxin, MIP- $1 \alpha$, and MCP-3, they do not indicate which receptors are involved in the chemotactic response to MCP-4.

Thus, to analyze further the receptors which may be involved in mediating MCP-4 activity, we performed chemotaxis experiments using the mouse pre-B lymphoma cell line 300.19 transfected with CCR2b (Fig. $5 A$ ) and the mouse pre-B lymphoma cell line L1.2 transfected with CCR3 (Fig. $5 B$ ). CCR2b is known to be a functional receptor for MCP-1 and MCP-3 $(60,61)$ and it is expressed on monocytes and lymphocytes, but not on eosinophils (31).

The results of these experiments indicate that CCR2b can also mediate a response to MCP-4, albeit at relatively high concentrations $(50-1,000 \mathrm{nM})$. As expected, eotaxin, which is
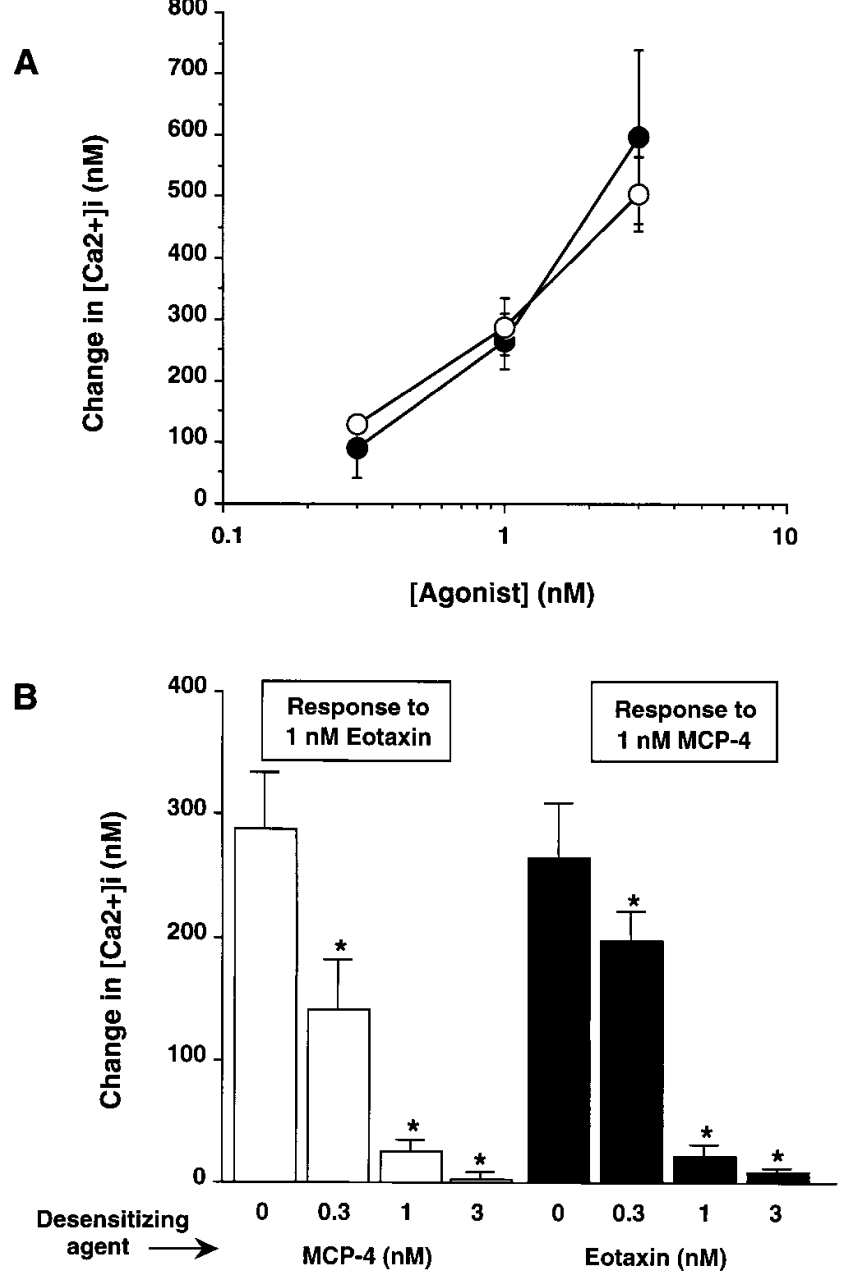

Figure 3. (A) Elevation of intracellular calcium induced by MCP-4 in eosinophils: comparison with eotaxin. MCP-4 and eotaxin at the concentrations indicated were added to Fura-2-loaded eosinophils and the peak change in intracellular calcium levels was measured. Results are expressed as the mean \pm SEM of $n=4$ experiments using different eosinophil preparations. Filled circles, MCP-4; open circles, eotaxin. (B) Desensitization of the calcium response between MCP-4 and eotaxin in eosinophils. Eosinophils were pretreated with the desensitizing agent $140 \mathrm{~s}$ before measurement of the peak change in intracellular calcium levels induced by exposure to the second agonist. Eosinophils showed complete homologous desensitization to repeated stimulation with the same chemokine (data not shown). Results are expressed as the mean \pm SEM of $n=4$ experiments using different eosinophil preparations. ${ }^{*} P<0.05$ compared with the response with no pretreatment.

known to selectively activate CCR3 (37), did not induce migration of CCR2b-transfected cells. Also inactive on CCR2b transfectants were RANTES and MIP- $1 \alpha$, which are both ligands of the CCR1, CCR4, and CCR5 receptors $(32,33)$. MCP-4 also induced the migration of CCR3-transfected cells, although to a lesser extent than eotaxin, RANTES, and MCP-3, all known ligands for this receptor. CCR3 transfectants did not migrate in response to MIP- $1 \alpha$ and showed a weak response to the highest concentration of MCP-1 (1,000 nM).

The receptor specificity of the action of MCP-4 was further analyzed using binding of radiolabeled chemokinesto purified 


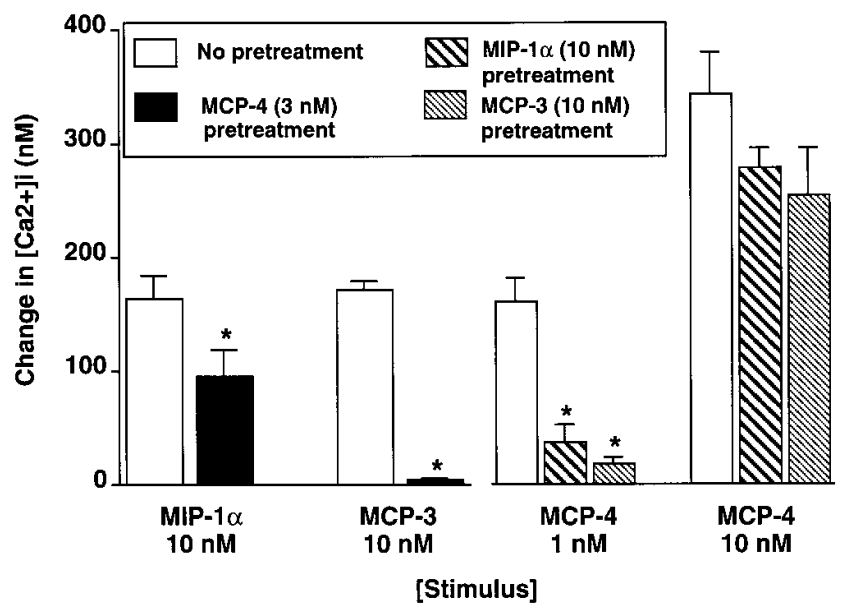

Figure 4. Desensitization of the calcium response in eosinophils between MCP-4, MIP-1 $\alpha$, and MCP-3. Eosinophils were pretreated with the indicated chemokines $140 \mathrm{~s}$ before measurement of the peak change in intracellular calcium levels induced by exposure to a second agonist. Eosinophils showed complete homologous desensitization to repeated stimulation with the same chemokine (data not shown). Results are expressed as the mean \pm SEM of $n=4$ experiments using different eosinophil preparations. ${ }^{*} P<0.05$ compared with the response with no pretreatment.

human peripheral blood eosinophils and receptor transfectants in the presence of cold MCP-4, eotaxin, RANTES, MCP-3, MCP-1, and MIP-1 $\alpha$. In purified peripheral blood eosinophils (Fig. $6 \mathrm{~A}$ ) we observed that cold eotaxin was the most potent inhibitor of the binding of radiolabeled eotaxin $\left(\mathrm{IC}_{50}=\right.$ $0.15 \pm 0.06 \mathrm{nM})$. MCP-4 was also a potent inhibitor of ${ }^{125} \mathrm{I}$-eotaxin binding to eosinophils $\left(\mathrm{IC}_{50}=0.85 \pm 0.35 \mathrm{nM}\right)$. RANTES, on the other hand, required concentrations $\sim 100$-fold higher than eotaxin or MCP-4 to inhibit binding of radiolabeled eotaxin. In the experiments shown in Fig. 6 A, cold MCP-3 inhibited ${ }^{125}$ I-eotaxin binding with a potency 10 -fold lower than MCP-4 ( $\mathrm{IC}_{50} \sim 10 \mathrm{nM}$ ). MCP-1 competed for binding only at relatively high concentrations (200-1,200 nM) and MIP- $1 \alpha$ had no effect on ${ }^{125}$ I-eotaxin binding. When CCR2b-transfected cells were used and ${ }^{125} \mathrm{I}-\mathrm{MCP}-1$ was the radiolabeled ligand
(Fig. $6 \mathrm{~B}$ ), MCP-3 was most effective among all the chemokines tested in inhibiting binding $\left(\mathrm{IC}_{50} \sim 1.8 \mathrm{nM}\right)$. MCP-4 competed with ${ }^{125} \mathrm{I}-\mathrm{MCP}-1$ for receptor binding less effectively than MCP-1 ( $\mathrm{IC}_{50} \sim 20$ and $6 \mathrm{nM}$, respectively). Interestingly, eotaxin inhibited ${ }^{125} \mathrm{I}-\mathrm{MCP}-1$ binding as well, although fivefold less effectively than MCP-4 ( $\left.\mathrm{IC}_{50} \sim 100 \mathrm{nM}\right)$. MIP- $1 \alpha$ and RANTES did not compete for CCR2b binding, as previously reported (62). In CCR3-transfected cells (Fig. $6 \mathrm{C}$ ), MCP-4 was the most potent competitor of ${ }^{125}$ I-eotaxin binding after cold eotaxin $\left(\mathrm{IC}_{50}=5\right.$ and $3 \mathrm{nM}$, respectively). $\mathrm{MCP}-3$ required concentrations of two orders of magnitude higher $\left(\mathrm{IC}_{50}=\right.$ $200 \mathrm{nM})$ to inhibit ${ }^{125} \mathrm{I}$-eotaxin binding. RANTES displaced ${ }^{125}$ I-eotaxin binding only at higher concentrations (200-600 $\mathrm{nM}$ ), and MIP- $1 \alpha$ did not compete for CCR3 binding. These studies further indicate that MCP-4 can bind to both CCR2b and CCR3.

To determine whether MCP-4 is expressed in vivo, poly $(\mathrm{A})^{+}$ RNA isolated from different human organs was analyzed by Northern blot. MCP-4 mRNA was markedly expressed in heart and lung. A weaker expression was observed in placenta, liver, and pancreas and no MCP-4 mRNA was detectable in brain tissue (Fig. $7 A$ ). The expression of MCP-4 mRNA in human lung tissue was confirmed by another Northern blot, using total RNA (data not shown). Expression of MCP-4 mRNA was also detected by RT-PCR in BAL cells harvested from both normal donors and asthmatic patients (Fig. 7 B). Airway epithelial cells have been reported to generate chemokines, including IL-8, GRO- $\alpha$, MCP-1 $(63,64)$, RANTES $(65,66)$, and eotaxin $(16,17)$. Preliminary results with immunohistochemical staining of human nasal polyp tissue suggest that MCP-4 may be produced by epithelial cells in vivo (data not shown). Therefore, we performed pilot studies to determine MCP-4 mRNA expression in several human airway epithelial cell lines after stimulation with cytokines. Studies displayed in Fig. $8 \mathrm{~A}$ demonstrate that the human bronchial epithelial cell lines BEAS-2B, A549, and IB3-1 expressed MCP-4 mRNA after stimulation for $24 \mathrm{~h}$ with TNFo $(100 \mathrm{ng} / \mathrm{ml})$ alone or in combination with IFN $\gamma(100 \mathrm{ng} / \mathrm{ml})$. Expression of MCP-4 was detectable in BEAS-2B cells after $3 \mathrm{~h}$ of stimulation with TNF $\alpha$ $(100 \mathrm{ng} / \mathrm{ml})$, with no further increase in the production after $24 \mathrm{~h}$ of incubation (data not shown). Human endothelial cells isolated from umbilical vein also expressed MCP-4 mRNA
A

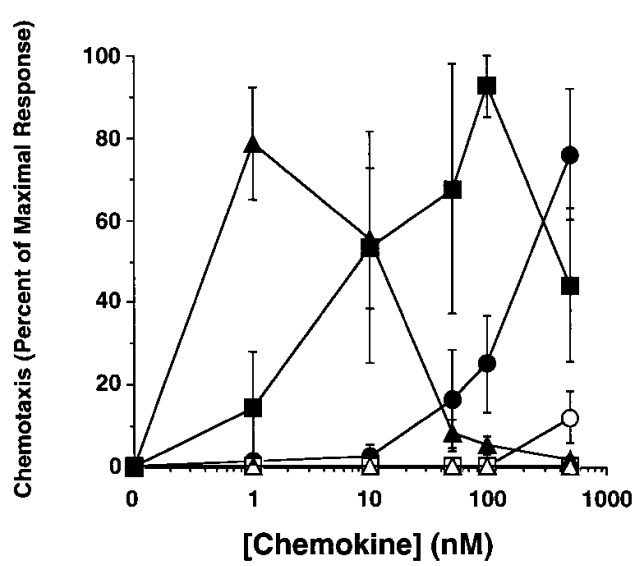

B

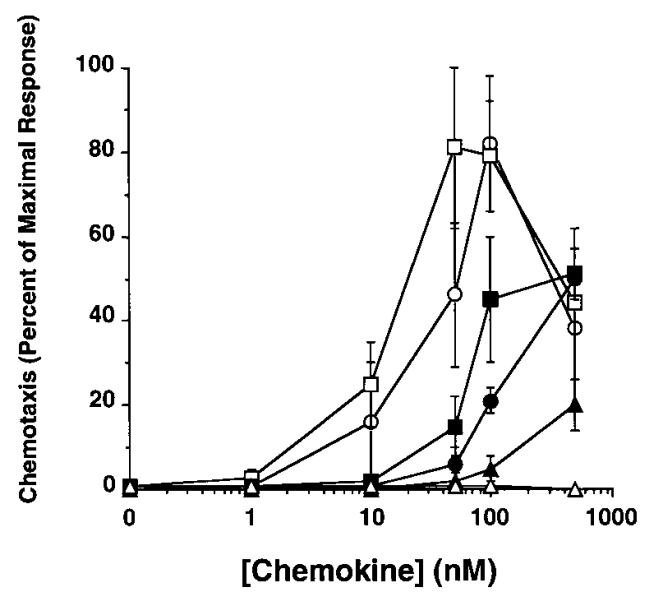

Figure 5. C-C chemokineinduced chemotaxis of the mouse pre-B lymphoma cell line 300.19 transfected with CCR2b (Fig. 5 $A, n=3$ ) and of the mouse preB lymphoma cell line L1.2 transfected with CCR3 (Fig. $5 \mathrm{~B}$, $n=3)$. Chemotaxis was assessed using bare filter assays in Biocoat $^{\circledR}$ transwell tissue culture plates as described in Methods. Filled circles, MCP-4; open circles, eotaxin; open squares, RANTES; filled squares, MCP-3; filled triangles, MCP-1; open triangles, MIP- $1 \alpha$. 


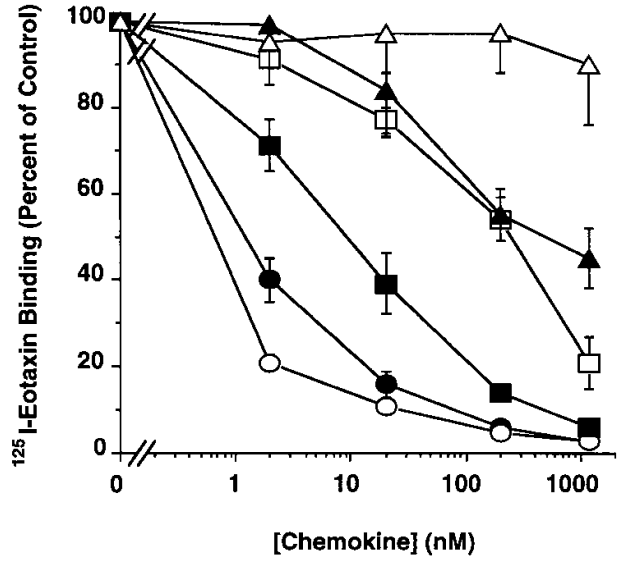

B

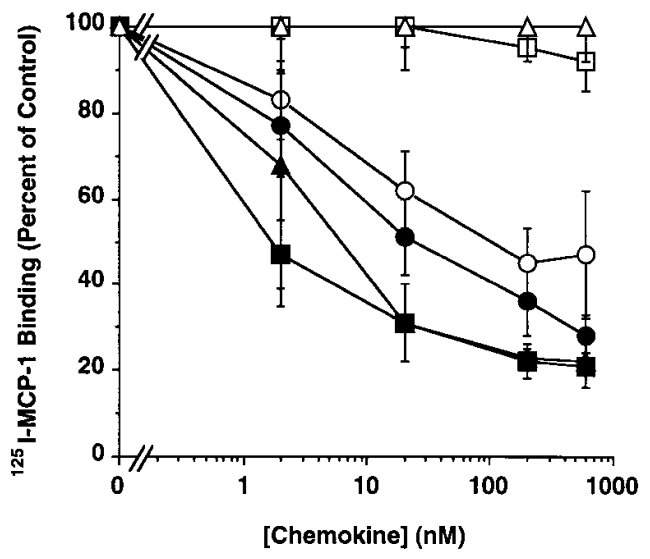

C

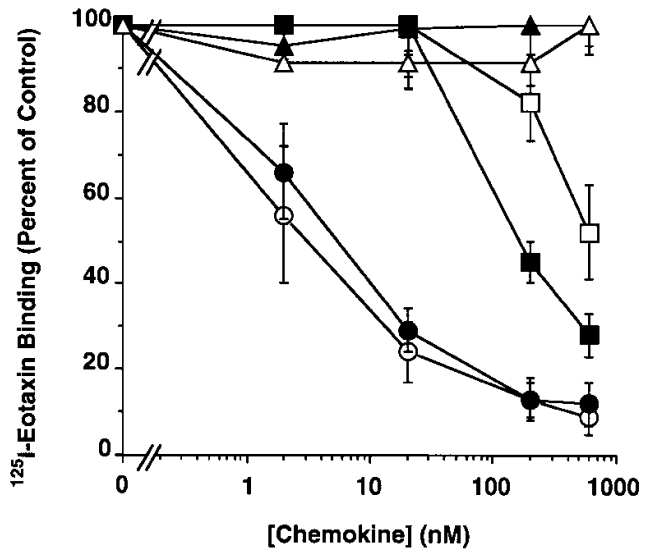

Figure 6. Competitive inhibition of ${ }^{125} \mathrm{I}$-eotaxin binding to eosinophils $(A)$ and to CCR3-transfectants $(C)$ and ${ }^{125} \mathrm{I}-\mathrm{MCP}-1$ binding to CCR2b-transfectants $(B)$ by C-C chemokines. $(A)$ Eosinophils $(n=3)$ were incubated with $0.1 \mathrm{nM}^{125}$ I-labeled eotaxin and 2, 20, 200 , and 1,200 nM of unlabeled MCP-4, eotaxin, RANTES, MCP-3, $\mathrm{MCP}-1$, and MIP- $1 \alpha$. After $1 \mathrm{~h}$ at $37^{\circ} \mathrm{C}$, cell pellets were washed and counted as described in Methods. $(B)$ The mouse lymphoma cell line 300.19 transfected with CCR2b was used to perform these experiments $(n=3)$ according to the protocol described for eosinophils. Cells were incubated with $0.1 \mathrm{nM}^{125}$ I-labeled MCP-1 and 2, 20, 200, and $600 \mathrm{nM}$ of unlabeled MCP-4, eotaxin, MCP-3, and MIP-1 $\alpha .(C)$ The lymphoma cell line L1.2 transfected with CCR3 was used for these experiments $(n=3)$. Cells were incubated with $0.1 \mathrm{nM}$ ${ }^{125}$ I-labeled eotaxin and 2, 20, 200, and $600 \mathrm{nM}$ of unlabeled MCP-4, eotaxin, RANTES, MCP-3, and MIP-1 $\alpha$. Filled circles, MCP-4; open circles, eotaxin; open squares, RANTES; filled squares, MCP-3; filled triangles, MCP-1; open triangles, MIP- $1 \alpha$.
A

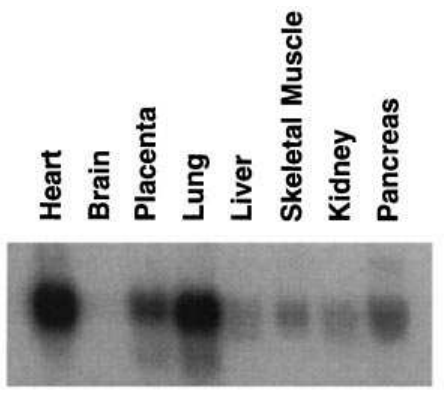

II.
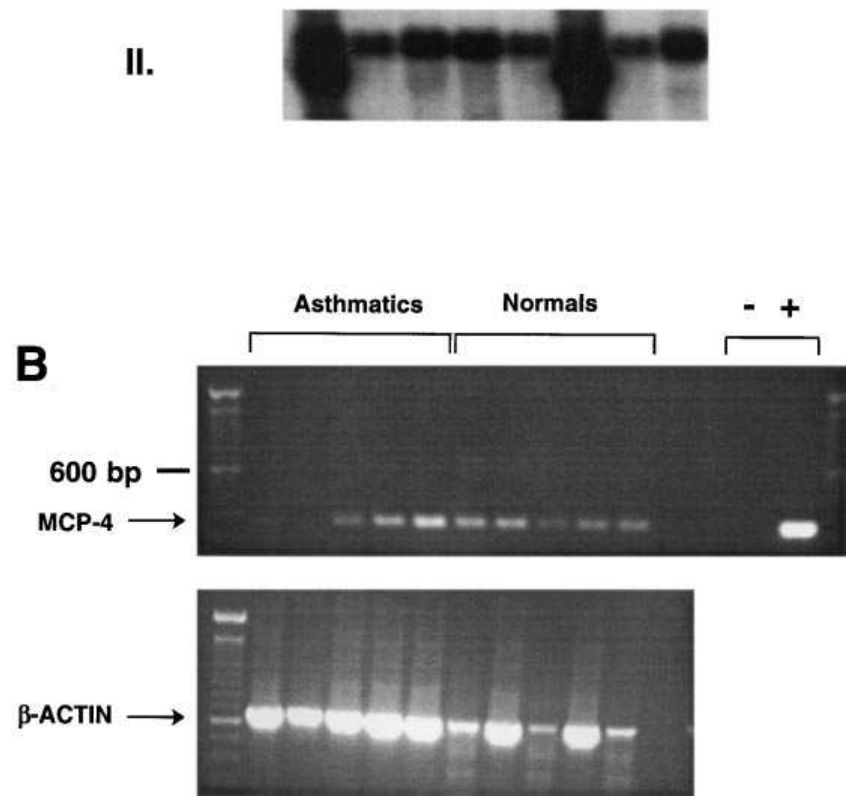

Figure 7. (A) Northern blot analysis of poly $(\mathrm{A})^{+}$RNA isolated from several human tissues. (I) Autoradiography of MCP-4 mRNA expression. (II) $\beta$-Actin mRNA expression from the same blot, after removal of MCP-4 specific probe, showing integrity of RNA and equal loading of lanes. $(B)$ Detection of mRNA for MCP-4 in BAL cells. MCP-4 mRNA was detected by RT-PCR in samples from five BAL cell preparations from unchallenged normal donors and five preparations from mild, unchallenged asthmatic patients. - is the no-template negative control; + is Bluescript plasmid containing MCP-4 coding region used as a positive control. Total RNA was reverse-transcribed and amplified by PCR using MCP-4 (top) and $\beta$-actin (bottom) specific primers.

upon stimulation with $\mathrm{TNF} \alpha$ and IFN $\gamma$, whereas no MCP-4 mRNA was detected in the human mast cell line HMC-1 when cells were treated for $4 \mathrm{~h}$ with TPA $(50 \mathrm{ng} / \mathrm{ml})$ and the $\mathrm{Ca}^{2+}$ ionophore A23187 $\left(10^{-7} \mathrm{M}\right)$ (data not shown). We also assessed the effect of exposure of BEAS-2B cells to $10^{-7} \mathrm{M}$ budesonide or DMSO diluent for $24 \mathrm{~h}$ before stimulation with the above mentioned cytokines on production of mRNA for MCP-4 (Fig. $8 \mathrm{~B}$ ). As has been observed with RANTES expression in the BEAS-2B cells (66), budesonide was an effective inhibitor of the expression of MCP-4 RNA. The effect observed with budesonide is glucocorticoid specific, since it was observed with hydrocortisone, but not with $\beta$-estradiol (data not shown).

\section{Discussion}

Recruitment of eosinophils to the lungs is a pivotal event in allergic airways pathology associated with asthma or allergic 

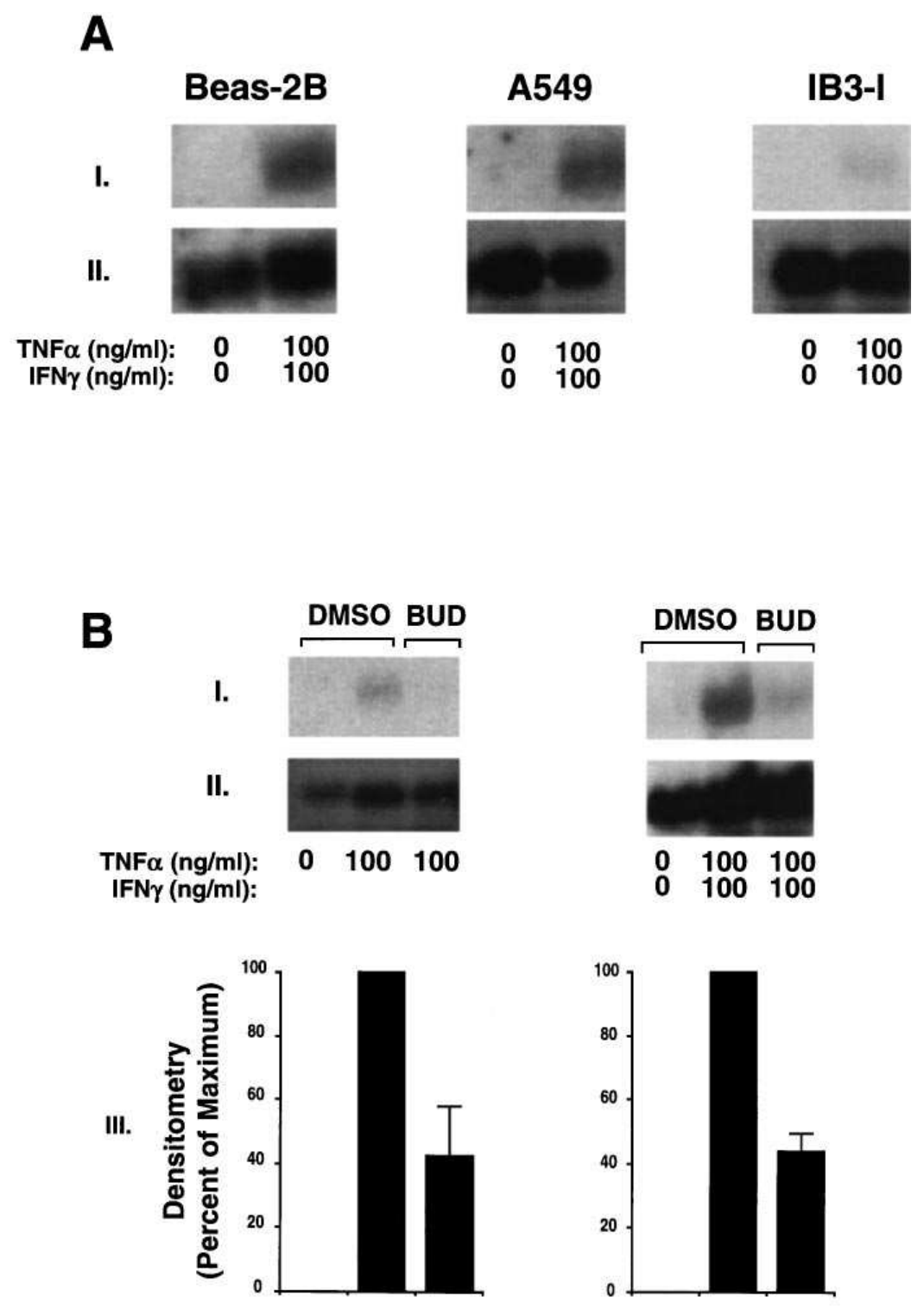

Figure 8. Detection of MCP-4 mRNA by Northern blot analysis in human bronchial epithelial cell lines: modulation by cytokines $(A)$ and the glucocorticoid budesonide $(B)$. ( $A$ ) Expression of MCP-4 mRNA after incubation of the human bronchial epithelial cell lines BEAS-2B, A549, and IB3-1 for $24 \mathrm{~h}$ with TNF $\alpha$ $(100 \mathrm{ng} / \mathrm{ml})$ and IFN $\gamma(100 \mathrm{ng} / \mathrm{ml})$. (I) Autoradiography of MCP-4 mRNA expression (representative of $n=5$ for BEAS-2B, $n=2$ for A549 and IB3-I). (II) G3PDH mRNA expression showing integrity of RNA and equal loading of lanes. $(B)$ Expression of MCP-4 mRNA after incubation of BEAS-2B cells for $24 \mathrm{~h}$ with TNF $\alpha(100 \mathrm{ng} / \mathrm{ml})$ alone (left) or with IFN $\gamma$ $(100 \mathrm{ng} / \mathrm{ml})($ right $)$ after pretreatment for $24 \mathrm{~h}$ with $10^{-7} \mathrm{M}$ budesonide or DMSO diluent. (I) Autoradiography of MCP-4 mRNA expression (representative of $n=3$ ). (II) G3PDH mRNA expression showing integrity of RNA and equal loading of lanes. (III) Mean densitometric analysis of the experiments.

rhinitis $(1,2)$. While recent studies indicate an important role for endothelial activation by cytokines such as IL-4, IL-1, and $\mathrm{TNF} \alpha$ as well as eosinophil priming by cytokines such as IL-5, IL-3, and GM-CSF, an increasing appreciation for the potential role of chemokines has evolved. Chemokines are now recognized to be essential participants in the sequence of events by which circulating cells are induced to roll on endothelium, adhere, and migrate across the vascular wall (3). With the identification of more than 30 different chemokine molecules, the chemokines also offer the potential to play a role in cell type-selective recruitment. This study focuses on a newly recognized chemokine discovered by mass cDNA sequencing, MCP-4. While many chemokines have been discovered by purification and sequencing of biologically active material (20, 67), many others, especially in the C-C subfamily, have been discovered using molecular biological tools, including subtraction library screening, homology-based cloning, and mass cDNA sequencing (13). We found that MCP-4 is a potent and effective eosinophil chemoattractant. MCP-4 probably induces migration of eosinophils through at least two receptors, including CCR2b and CCR3. MCP-4 also activates IL-3-primed pe- ripheral blood basophils to release histamine. MCP-4 mRNA was found in human lung and in cells present in the lumen of the airways and is produced by cultured airway epithelial cells upon stimulation with cytokines. Finally, epithelial production of MCP-4 is inhibited by prior exposure to the potent inhaled glucocorticoid budesonide. Together, these results suggest that MCP-4 should be considered among the chemokines of potential relevance to the localization of eosinophils in allergic diseases of the airways.

In comparison with other eosinophil-active C-C chemokines, MCP-4 was found to be the most potent in inducing the migration of purified peripheral blood eosinophils. However, the relative potency of chemokines has shown some degree of variability among the different experimental models used in this study and, in general, the assessment of their relative potency as eosinophil chemoattractants has varied among reports from different laboratories $(16,17)$. MCP-4-mediated activation of eosinophils was associated with an increase in intracytoplasmic calcium levels which had a dose dependence similar to that observed for chemotactic responses.

Among the $\mathrm{C}-\mathrm{C}$ chemokines, $\mathrm{MCP}-1$ and $\mathrm{MCP}-3$ are 
known to be potent basophil activators (19). In this study, MCP-4 induced a significant release of histamine by IL-3primed peripheral blood basophils, which was comparable with that induced by MCP-3. Thus, MCP-4 is able to activate basophils and eosinophils, both cell types involved in allergic reactions.

Experiments with cross-desensitization in eosinophils using eotaxin, MCP-3, and MIP- $1 \alpha$ suggest that this activation is mediated through at least two CCRs. The equal cross-desensitization observed between MCP-4 and eotaxin suggests that MCP-4 can induce calcium mobilization after binding to the eotaxin receptor, CCR3 (16). Furthermore, the ability of MCP-4 to partially desensitize the response to MIP- $1 \alpha$ and abolish the response to MCP-3 implies that MCP-4 can activate eosinophils by binding to other chemokine receptors, such as CCR1.

The high homology of MCP-4 with MCP-3, especially in the functionally important $\mathrm{NH}_{2}$ terminus, also implicates CCR2b, which is known to be a receptor for MCP subfamily members (31). Although CCR2b may not be expressed or relevant in eosinophils, the functional binding of MCP-4 to $\mathrm{CCR} 2 \mathrm{~b}$ is also suggested by data indicating that this molecule induces migration of peripheral blood monocytes (43). Direct evidence demonstrating an interaction of MCP-4 with CCR2b and CCR3 was obtained in chemotaxis experiments and competition binding experiments using mouse cells transfected with these two receptors. MCP-4 induced migration of both transfectants, demonstrating that either receptor could mediate a productive MCP-4 signal. On the other hand, eotaxin was active on the CCR3-transfected cells but not the CCR2-transfected cells, suggesting a more limited range of targets for this chemokine. Inhibition of ${ }^{125}$ I-eotaxin binding by MCP-4 supports the conclusion that MCP-4 can bind to CCR3. Although MCP-4 was a potent inhibitor of binding of labeled MCP-1 to CCR2b-transfectants or eotaxin to CCR3-transfectants, it was not as potent in inducing migration of the transfectants as it was for peripheral blood eosinophils (see Figs. 2 and 5). This is likely due to the fact that the transfected cells are transformed mouse pre-B cells, which are not normally very migratory; thus, they probably do not possess locomotor machinery comparable with normal peripheral blood leukocytes. Furthermore, there may be species differences affecting efficient signaling. Whether CCR 1 or 4 are able to ligand with MCP-4 is unknown. However, the cross-desensitization with MIP- $1 \alpha$ suggests that CCR1 may be capable of binding MCP-4.

The in vivo relevance of findings with MCP-4 is yet to be established. Ultimately, the biological role of the different chemokines will depend on timing of chemokine production, localization of the chemokine signal, and either preexisting or antigen-induced cofactors such as the presence of endothelial activation and eosinophil priming. The analysis of MCP-4 mRNA expression in various human tissues revealed that this chemokine is not ubiquitously expressed. The marked expression of mRNA for MCP-4 in the lung, as well as its detection in the cells recovered from airways by BAL indicates that $\mathrm{MCP}-4$ may be produced in vivo predominantly in the airways. Whether MCP-4 is upregulated in inflammatory conditions is yet unknown; the nonquantitative RT-PCR analysis we performed on BAL cells did not detect an obvious difference between control and mild asymptomatic asthmatics. The influence of antigen challenge will be determined in future studies.

The potential cellular sources of MCP-4 in the airways are also presently under investigation. BAL cells collected from asthmatic subjects are predominantly macrophages and eosinophils. However, monocytes and lymphocytes can be found in the BAL fluid as well as epithelial cells and neutrophils in some cases. Experiments using three different human epithelial cell lines indicate that MCP-4 mRNA expression can be induced in airway epithelial cells upon stimulation with proinflammatory cytokines. In fact, Northern blot and RT-PCR assays indicated that epithelial cells cultured in the presence of the cytokines $\mathrm{TNF} \alpha$ and IFN $\gamma$, which are optimal stimuli for RANTES production, expressed mRNA for MCP-4 while unstimulated epithelial cells did not. Whether lower airway epithelial cells produce MCP-4 mRNA or product in vivo in asthmatics or after antigen challenge would be of significant interest to determine.

The potent inhaled glucocorticoid budesonide was an effective inhibitor of the expression of MCP-4 mRNA in cultured BEAS-2B epithelial cells activated with cytokines in vitro. Epithelial cells are the first cell type to come in contact with inhaled glucocorticoids. Previous studies from our laboratories and others have shown that epithelial cell production of several cytokines, including GM-CSF, RANTES, MCP-1, and IL-6, is inhibited by exposure of these cells to glucocorticoids (68). These findings lead to the hypothesis that epithelial cells are an important source of proinflammatory cytokines in the airways and an important target of the antiinflammatory effects of inhaled glucocorticoids. Since inhaled glucocorticoids now represent in many cases the drug of first choice for the treatment of allergic airways disease, these findings must be considered of relevance to the therapeutic management of asthma.

In summary, we have found that a newly identified beta or $\mathrm{C}-\mathrm{C}$ chemokine, MCP-4, was a potent and effective eosinophil chemoattractant and basophil activator which is produced by airway epithelial cells and in vivo in bronchoalveolar cells. Production of MCP-4 mRNA is inhibited in epithelial cells by glucocorticoids and the actions of MCP-4 are likely to involve several different CCRs, including CCR1, 2, and 3. Since this chemokine is a potent eosinophil chemoattractant, is produced by airway epithelial and other airway cells, and is a target of glucocorticoids, considerations of the mechanisms of allergic airways eosinophil recruitment should include the possibility that MCP-4 participates.

\section{Acknowledgments}

The authors would like to thank Dr. Lisa A. Beck and Dr. Vincenzo Casolaro for helpful discussions, Mr. James R. Plitt, Ms. Sherry A. Sterbinsky, Ms. Juan Wang, and Mr. ZhiMen Shen for their expert technical assistance, and Ms. Bonnie Hebden for skilled assistance in the preparation of the manuscript.

This work was supported by National Institutes of Health grants RO1-AR 31891 and AI31867 and a gift from ASTRA DRACO-ASTRA USA; the National Asthma Campaign, United Kingdom, and the Wellcome Trust, United Kingdom (programme grant 038775). Dr. C. Stellato is the recipient of a Fogarty International Fellowship Award.

\section{References}

1. Weller, P.F. 1991. The immunobiology of eosinophils. N. Engl. J. Med. 324:1110-1118.

2. Sur, S., C.R. Adolphson, and G.J. Gleich. 1993. Eosinophils: biochemical and cellular aspects. In Allergy Principles and Practice. 4th Ed. E. Middleton, C.E. Reed, E.F. Ellis, J.N.F. Adkinson, J.W. Yunginger, and W. Busse, editors. Mosby, St. Louis, MO. 169-200. 
3. Bochner, B.S., and R.P. Schleimer. 1994. The role of adhesion molecules in human eosinophil and basophil recruitment. J. Allergy Clin. Immunol. 94: 427-438.

4. Bochner, B.S., F.W. Luscinskas, M.A. Gimbrone, Jr., W. Newman, S.A. Sterbinsky, C. Derse-Anthony, D. Klunk, and R.P. Schleimer. 1991. Adhesion of human basophils, eosinophils, and neutrophils to IL-1-activated human vascular endothelial cells. Contributions of endothelial cell adhesion molecules. $J$. Exp. Med. 173:1553-1557.

5. Weller, P.F., T.H. Rand, S.E. Goelz, G. Chi-Rosso, and R.R. Lobb. 1991 Human eosinophil adherence to vascular endothelium mediated by binding to vascular cell adhesion molecule 1 and endothelial leukocyte adhesion molecule 1. Proc. Natl. Acad. Sci. USA. 88:7430-7433.

6. Dobrina, A., R. Menegazzi, T.M. Carlos, E. Nardon, R. Cramer, T. Zacchi, J.M. Harlan, and P. Patriarca. 1991. Mechanisms of eosinophil adherence to cultured vascular endothelial cells. Eosinophils bind to the cytokine-induced endothelial ligand vascular cell adhesion molecule- 1 via the very late activation antigen-4 integrin receptor. J. Clin. Invest. 88:20-26.

7. Bochner, B.S., D.A. Klunk, S.A. Sterbinsky, R.L. Coffman, and R.P. Schleimer. 1995. Interleukin-13 selectively induces vascular cell adhesion molecule-1 (VCAM-1) expression in human endothelial cells. J. Immunol. 154:799803.

8. Fujisawa, T., R. Abu-Ghazaleh, H. Kita, C.J. Sanderson, and G.J. Gleich. 1990. Regulatory effect of cytokines on eosinophil degranulation. J. Immunol. 144:642-646.

9. Sehmi, R., A.J. Wardlaw, O. Cromwell, K. Kurihara, P. Waltmann, and A.B. Kay. 1992. Interleukin-5 selectively enhances the chemotactic response of eosinophils obtained from normal but not eosinophilic subjects. Blood. 79: 2952-2959.

10. Ebisawa, M., M.C. Liu, T. Yamada, M. Kato, L.M. Lichtenstein, B.S. Bochner, and R.P. Schleimer. 1994. Eosinophil transendothelial migration induced by cytokines. II. The potentiation of eosinophil transendothelial migration by eosinophil-active cytokines. J. Immunol. 152:4590-4597.

11. Walsh, G.M., A. Hartnell, A.J. Wardlaw, K. Kurihara, C.J. Sanderson, and A.B. Kay. 1990. IL-5 enhances the in vitro adhesion of human eosinophils, but not neutrophils, in a leukocyte integrin (CD11/18)-dependent manner. Immunology. 71:258-265.

12. Oppenheim, J.J., C.O.C. Zachariae, N. Mukaida, and K. Matsushima 1991. Properties of the novel proinflammatory supergene "intercrine" cytokine family. Annu. Rev. Immunol. 9:617-648.

13. Schall, T.J. 1991. Biology of the RANTES/SIS cytokine family. Cytokine. 3:165-183.

14. Baggiolini, M., and C.A. Dahinden. 1994. CC chemokines in allergic inflammation. Immunol. Today. 15:127-133.

15. Taub, D.D., and J.J. Oppenheim. 1994. Chemokines, inflammation and the immune system. Ther. Immunol. 1:229-246.

16. Ponath, P.D., S. Qin, D.J. Ringler, I. Clark-Lewis, J. Wang, N. Kassam, H. Smith, J.-A. Bonzalo, W. Newman, J.-C. Gutierrez-Ramos, and C.R. MacKay. 1996. Cloning of the human eosinophil chemoattractant, eotaxin. Expression, receptor binding and function properties provide a mechanism for the selective recruitment of eosinophils. J. Clin. Invest. 97:604-612.

17. Garcia-Zepeda, E.A., M.E. Rothenberg, R.T. Ownbey, J. Celestin, P. Leder, and A. Luster. 1996. Human eotaxin is a specific chemoattractant for eosinophil cells and provides new mechanism to explain tissue eosinophilia. Nat. Med. 4:449-456.

18. Kameyoshi, Y., A. Dorschner, A.I. Mallet, E. Christophers, and J.M. Schroder. 1992. Cytokine RANTES released by thrombin-stimulated platelets is a potent attractant for human eosinophils. J. Exp. Med. 176:587-592.

19. Dahinden, C.A., T. Geiser, T. Brunner, V. von Tscharner, D. Caput, P. Ferrara, A. Minty, and M. Baggiolini. 1994. Monocyte chemotactic protein 3 is a most effective basophil- and eosinophil-activating chemokine. J. Exp. Med. 179:751-756.

20. Jose, P.J., D.A. Griffiths-Johnson, P.D. Collins, D.T. Walsh, R. Moqbel, N.F. Totty, O. Truong, J.J. Hsuan, and T.J. Williams. 1994. Eotaxin: a potent eosinophil chemoattractant cytokine detected in a guinea pig model of allergic airways inflammation. J. Exp. Med. 179:881-887.

21. Rot, A., M. Krieger, T. Brunner, S.C. Bischoff, T.J. Schall, and C.A. Dahinden. 1992. RANTES and macrophage inflammatory protein $1 \alpha$ induce the migration and activation of normal human eosinophil granulocytes. J. Exp. Med. 176:1489-1495.

22. Bischoff, S.C., M. Krieger, T. Brunner, A. Rot, V. Vontscharner, M. Baggiolini, and C.A. Dahinden. 1993. RANTES and related chemokines activate human basophil granulocytes through different G-protein-coupled receptors. Eur. J. Immunol. 23:761-767.

23. Ying, S., L. Taborda-Barata, Q. Meng, M. Humbert, and A.B. Kay. 1995. The kinetics of allergen-induced transcription of messenger RNA for monocyte chemotactic protein-3 and RANTES in the skin of human atopic subjects. Relationship to eosinophil, T cell, and macrophage recruitment. J. Exp. Med. 181:2153-2159.

24. Rothenberg, M.E., A.D. Luster, C.M. Lilly, J.M. Drazen, and P. Leder. 1995. Constitutive and allergen-induced expression of eotaxin mRNA in the guinea pig lung. J. Exp. Med. 181:1211-1216.

25. Jose, P.J., I.M. Adcock, D.A. Giffiths-Johnson, N. Berkman, T.N. Wells,
T.J. Williams, and C.A. Power. 1994. Eotaxin: cloning of an eosinophil chemoattractant cytokine and increased mRNA expression in allergen-challenge guinea pig lungs. Biochem. Biophys. Res. Commun. 205:788-794.

26. Teran, L.M., N. Noso, M. Carroll, D.E. Davies, S. Holgate, and J.-M. Schröder. 1996. Eosinophil recruitment following allergen challenge is associated with the release of the chemokine RANTES into asthmatic airways. J. Immunol. 157:1806-1812.

27. Meurer, R., G. Van Riper, W. Feeney, P. Cunningham, D. Hora, Jr., M.S. Springer, D.E. MacIntyre, and H. Rosen. 1993. Formation of eosinophilic and monocytic intradermal inflammatory sites in the dog by injection of human RANTES but not human monocyte chemoattractant protein 1, human macrophage inflammatory protein $1 \alpha$, or human interleukin 8. J. Exp. Med. 178: 1913-1921.

28. Beck, L., C. Bickel, S. Sterbinsky, C. Stellato, R. Hamilton, H. Rosen, B. Bochner, and R. Schleimer. 1995. Injection of human subjects with RANTES causes dermal infiltration of eosinophils (EOS) and mononuclear cells (MNC) FASEB (Fed. Am. Soc. Exp. Biol.) J. 9:804a. (Abstr.)

29. Griffiths-Johnson, D.A., P.D. Collins, A.G. Rossi, P.J. Jose, and T.J. Williams. 1993. The chemokine, eotaxin, activates guinea-pig eosinophils in vitro and causes their accumulation into the lung in vivo. Biochem. Biophys. Res. Commun. 197:1167-1172.

30. Collins, P.D., S. Marleau, D.A. Griffiths-Johnson, P.J. Jose, and T.J. Williams. 1995. Cooperation between interleukin-5 and the chemokine eotaxin to induce eosinophil accumulation in vivo. J. Exp. Med. 182:1169-1174.

31. Murphy, P.M. 1996. Chemokine receptors: structure, function and role in microbial pathogenesis. Cytokine and Growth Factors Reviews. 7:47-58.

32. Mackay, C.R. 1996. Chemokine receptors and T cell chemotaxis. J. Exp. Med. 184:799-802.

33. Neote, K., D. DiGregorio, J.Y. Mak, R. Horuk, and T.J. Schall. 1993. Molecular cloning, functional expression, and signaling characteristics of a C-C chemokine receptor. Cell. 72:415-425.

34. Combadiere, C., S.K. Ahuja, and P.M. Murphy. 1995. Cloning and functional expression of a human eosinophil CC chemokine receptor. J. Biol. Chem. 270:16491-16494.

35. Power, C.A., A. Meyer, K. Nemeth, K.B. Bacon, A.J. Hoogewerf, A.E. Proudfoot, and T.N. Wells. 1995. Molecular cloning and functional expression of a novel CC chemokine receptor cDNA from a human basophilic cell line. $J$. Biol. Chem. 270:19495-19500.

36. Chaudhuri, A., V. Zbrzezna, J. Polyakova, A.O. Pogo, J. Hesselgesser, and R. Horuk. 1994. Expression of the Duffy antigen in K562 cells. Evidence that it is the human erythrocyte chemokine receptor. J. Biol. Chem. 269:78357838 .

37. Ponath, P.D., S. Oin, T.W. Post, J. Wang, L. Wu, N.P. Gerard, W. Neuman, C. Gerard, and C. R. Mackay. 1996. Molecular cloning and characterization of a human eotaxin receptor expressed selectively on eosinophils. J. Exp. Med. 183:2437-2448.

38. Combadiere, C., S. Ahuja, H.L. Tiffany, and P.M. Murphy. 1996. Cloning and functional expression of CC CKR5, a human monocyte CC chemokine receptor selective for MIP-1 $\alpha$, MIP-1 $\beta$, and RANTES. J. Leuk. Biol. 60:147152

39. Peiper, S.C., Z.X. Wang, K. Neote, A.W. Martin, H.J. Showell, M.J. Conklyn, K. Ogborne, T.J. Hadley, Z.H. Lu, and J. Hesselgesser. 1995. The duffy antigen/receptor for chemokines (DARC) is expressed in endothelial cells of Duffy negative individuals who lack the erythrocyte receptor. J. Exp. Med. 181:1311-1317.

40. Hadley, T.J., Z. Lu, K. Wasniowska, A.W. Martin, S.C. Peiper, J. Hesselgesser, and R. Horuk. 1994. Postcapillary venule endothelial cells in kidney express a multispecific chemokine receptor that is structurally and functionally identical to the erythroid isoform, which is the duffy blood group antigen. $J$. Clin. Invest. 94:985-991.

41. Neote, K., J.Y. Mak, L.F. Kolakowski, and T.J. Schall. 1994. Functional and biochemical analysis of the cloned Duffy antigen: identity with the red blood cell chemokine receptor. Blood. 84:44-52.

42. Stellato, C., L. Beck, L. Schweibert, H. Li, J. White, and R.P. Schleimer. 1996. A novel C-C chemokine, CK $\beta 10$, is expressed in airway epithelial cells and is a potent eosinophil chemoattractant. J. Allergy Clin. Immunol. 97:304.

43. Uguccioni, M., P. Loetscher, U. Forssmann, B. Dewald, H. Li, S.H Lima, H. Li, B. Kreider, G. Barotta, M. Thelen, and M. Baggiolini. 1996. Monocyte chemotactic protein 4 (MCP-4), a novel structural and functional analogue of MCP-3 and eotaxin. J. Exp. Med. 183:2379-2384.

44. Clark-Lewis, I., B. Moser, A. Walz, M. Baggiolini, G.J. Scott, and R. Aebersold. 1991. Chemical synthesis, purification, and characterization of two inflammatory proteins, neutrophil activating peptide 1 (interleukin 8 ) and neutrophil activating peptide. Biochemistry. 30:3128-3135.

45. Reddel, R.R., Y. Ke, B.I. Gerwin, M.G. McMenamin, J.F. Lechner, R.T. Su, D.E. Brash, P.-B. Park, J.S. Rhim, and C.C. Harris. 1988. Transformation of human bronchial epithelial cells by infection with SV40 or adenovirus-12 SV4hybrid virus, or transfection via strontium phosphate coprecipitation with a plasmid containing SV40 early region genes. Cancer Res. 48:1904-1909.

46. Zeitlin, P.L., L. Lu, J. Rhim, G. Cutting, G. Stretten, K.A. Keiffer, R. Craig, and W.B. Guggino. 1991. A cystic fibrosis bronchial epithelial cell line: immortalization by adenovirus $12-S V 40$ infection. Am. J. Respir. Cell Mol. Biol. 
4:313-317.

47. Liu, M.C., E.R. Bleecker, L.M. Lichtenstein, A. Kagey-Sobotka, Y. Niv, T.L. McLemore, S. Permutt, D. Proud, and W.C. Hubbard. 1990. Evidence for elevated levels of histamine, prostaglandin $\mathrm{D}_{2}$, and other bronchoconstricting substances in the airways of mild asthmatic subjects. Am. Rev. Respir. Dis. 142: $126-132$.

48. Warner, J.A., A. Reshef, and D.W. MacGlashan, Jr. 1987. A rapid Percoll technique for the purification of basophils. J. Immunol. Methods. 105:107110 .

49. Gilbert, H.S., and L. Ornstein. 1975. Basophil counting with a new staining method using Alcian blue. Blood. 46:279-286.

50. Hansel, T.T., I.J.M.D. Vries, T. Iff, S. Rihs, M. Wandzilak, S. Betz, K. Blaser, and C. Walker. 1991. An improved immunomagnetic procedure for the isolation of highly purified human blood eosinophils. J. Immunol. Methods. 145: $105-110$

51. Schleimer, R.P., and B.K. Rutledge. 1986. Cultured human vascular endothelial cells acquire adhesiveness for leukocytes following stimulation with interleukin-1, endotoxin, and tumor-promoting phorbol esters. J. Immunol. 136:649-654

52. Schleimer, R.P., S.A. Sterbinsky, J. Kaiser, C.A. Bickel, D.A. Klunk, K. Tomioka, W. Newman, F.W. Luscinskas, M.A. Gimbrone, Jr., B.W. McIntyre, and B.S. Bochner. 1992. Interleukin-4 induces adherence of human eosinophils and basophils but not neutrophils to endothelium: association with expression of VCAM-1. J. Immunol. 148:1086-1092.

53. Schleimer, R.P., H.S. Freeland, S.P. Peters, K.E. Brown, and C.P. Derse. 1989. An assessment of the effects of glucocorticoids on degranulation, chemotaxis, binding to vascular endothelial cells and formation of leukotriene B4 by purified human neutrophils. J. Pharmacol. Exp. Ther. 250:598-605.

54. Lichtenstein, L.M., and A.G. Osler. 1964. Studies on the mechanisms of hypersensitivity phenomena. J. Exp. Med. 120:507-530.

55. Siraganian, R.P. 1974. An automated continuous-flow system for the extraction and fluorometric analysis of histamine. Anal. Biochem. 57:383-391.

56. Chomczynski, P., and N. Sacchi. 1987. Single-step method of RNA isolation by acid guanidinium thiocyanate-phenol-chloroform extraction. Anal. Biochem. 162:156-159.

57. Saiki, R.K., T.L. Bugawan, G.T. Horn, K.B. Mullis, and H.A. Erlich. 1986. Analysis of enzymatically amplified beta-globin and HLA-DQ alpha
DNA with allele-specific oligonucleotide probes. Nature (Lond.). 324:163-166. 58. Sanger, F., S. Nicklen, and A.R. Couson. 1977. DNA sequencing with chain-terminating inhibitors. Proc. Natl. Acad. Sci. USA. 74:5463-5469.

59. Schuler, G.D., M.S. Boguski, E.A. Stewart, L.D. Stein, G. Gyapay, K. Rice, R.E. White, P. Rodriguez-Tomé, A. Aggarwal, E. Bajorek, et al. 1996. A gene map of the human genome. Science (Wash. DC). 274:540-546.

60. Charo, I.F., S.J. Myers, A. Herman, C. Franci, A.J. Connolly, and S.R. Coughlin. 1994. Molecular cloning and functional expression of two monocyte chemoattractant protein 1 receptors reveals alternative splicing of the carboxyterminal tails. Proc. Natl. Acad. Sci. USA. 91:2752-2758.

61. Franci, C., L.M. Wong, J. Van Damme, P. Proost, and I.F. Charo. 1995. Monocyte chemoattractant protein-3, but not monocyte chemoattractant protein-2, is a functional ligand of the human monocyte chemoattractant protein-1 receptor. J. Immunol. 154:6511-6517.

62. Myers, S.J., L.M. Wong, and I.F. Charo. 1995. Signal transduction and ligand specificity of the human MCP-1 (monocyte chemoattractant protein-1) receptor in transfected embryonic kidney cells. J. Biol. Chem. 270:5786-5791.

63. Nakamura, H., K. Yoshimura, H.A. Jaffe, and R.G. Crystal. 1991. Interleukin-8 gene expression in human bronchial epithelial cells. J. Biol. Chem. 266: 19611-19617.

64. Becker, S., J. Quay, H.S. Koren, and J.S. Haskill. 1994. Constitutive and stimulated MCP-1, GRO alpha, beta, and gamma expression in human airway epithelium and bronchoalveolar macrophages. Am. J. Physiol. 266:L278-L286.

65. Kwon, O.J., P.J. Jose, R.A. Robbins, T.J. Schall, T.J. Williams, and P.J. Barnes. 1996. Glucocorticoid inhibition of RANTES expression in human lung epithelial cells. Am. J. Respir. Cell. Mol. Biol. 12:488-496.

66. Stellato, C., L.A. Beck, G.A. Gorgone, D. Proud, T.J. Schall, S.J. Ono, L.M. Lichtenstein, and R.P. Schleimer. 1995. Expression of the chemokine RANTES by a human bronchial epithelial cell line: modulation by cytokines and glucocorticoids. J. Immunol. 155:410-418.

67. Wolpe, S.D., G. Davatelis, B. Sherry, B. Beutler, D.G. Hesse, H.T. Nguyen, L.L. Moldawer, C.F. Nathan, S.F. Lowry, and A. Cerami. 1988. Macrophages secrete a novel heparin-binding protein with inflammatory and neutrophil chemokinetic properties. J. Exp. Med. 167:570-581.

68. Schwiebert, L.M., L.A. Beck, C. Stellato, C.A. Bickel, B.S. Bochner, and R.P. Schleimer. 1996. Glucocorticosteroid inhibition of cytokine production: relevance to antiallergic actions. J. Allergy Clin. Immunol. 97:143-152. 